\section{Early Mention of the Term Epidemiology}

\section{José Tuells}

Author affiliation: University of Alicante, Alicante, Spain

DOI: http://dx.doi.org/10.3201/eid2211.141466

To the Editor: The excellent article on measures for controlling plague in Alghero, Sardinia, describes the procedures introduced by the Calabrian doctor Quinto Tiberio Angelerio (1532-1617) to combat an outbreak during 1582-1583 (1). The authors cite 2 works published by Angelerio relating to these events, Ectypa (1588) (2) and Epidemiologìa (1598) (3). To say that Epidemiologìa was written only in Spanish is a small error, however, because both works were written in Latin. Ectypa contains an appendix written in Catalan with the measures to take during an epidemic, whereas in Epidemiologìa, this appendix was written in Spanish.

A third and posthumous edition, not cited in the article, was found recently in the Bibliothèque Nationale de France (4). Epydem (5) was published in Naples in 1651 by Angelerio's nephew. This work was written in Latin and did not contain appendices but did include a brief biography of Angelerio. The terms epidemic (Greek) and plague (Latin) were used ambiguously to refer to "maladies that came from abroad or afflicted us collectively."

The major aspect of Angelerio's texts, especially Epidemiologì (3), is that the term epidemiology was used here for the first time in a "treatise on the plague" in the sense of "how to protect yourself from it when it erupts." The term was adopted by the Spanish physician Joaquín de Villalba (1752-1807) who, citing Angelerio, used it as the title for his work Epidemiología Española (6). This treatise gained wide circulation, and the term was espoused by various authors from the beginning of the 19th century onward. Villalba used it to compose a historical chronology of the epidemics in Spain, noting the type of disease and the place and year in which it had occurred; this was an initial approach to the concept of epidemiology, which coincided with the development of medical topographies and statistics applied to infectious diseases.

\section{References}

1. Bianucci R, Benedictow OJ, Fornaciari G, Giuffra V. Quinto Tiberio Angelerio and new measures for controlling plague in 16thcentury Alghero, Sardinia. Emerg Infect Dis. 2013;19:1478-83. http://dx.doi.org/10.3201/eid1909.120311

2. Angelerii QT. Ectypa pestilentis status Algheriae Sardiniae. Ad Ill D.D. Michaelem A. Moncada Regni Proregem etc. Calari: typ.Nic. Canelles per Franc.Guarnerium; 1588.

3. Angelerii QT. Epidemiologìa sive tractatus de peste, ad Regni Sardiniae Proregem. Madrid: ex Typographia Regia; 1598.
4. Pino Campos LM. The lost edition by Quintus Tiberius Angelerius. Fortunatae. 2012;23:113-33.

5. Angelerii QT. Epydem, historia Q. Tiberii Angelerii; novum opus, omni eruditione refertum; cunctis studiosis utile, et iucundum. Neap. Typ. Roberto Molli; 1651 [cited 2014 Aug 28]. http://gallica.bnf.fr/ark:/12148/bpt6k134450z/f1.image. r=Epydem,\%20historia\%20Q\%20Tiberii\%20Angelerii.langES

6. Villalba J. Epidemiología española. Madrid: Imprenta de D. Mateo Repullés; 1802

Address for correspondence: José Tuells, Cátedra Balmis de Vacunología, University of Alicante, Campus de San Vicente Raspeig Ap99, E-03080 Alicante, Spain; email: tuells@ua.es

\section{Travel-Associated Vibrio cholerae 01 El Tor, Russia}

\author{
Konstantin V. Kuleshov, Sergey O. Vodop'ianov, \\ Vladimir G. Dedkov, Mikhail L. Markelov, \\ Andrey A. Deviatkin, Vladimir D. Kruglikov, \\ Alexey S. Vodop'ianov, Ruslan V. Pisanov, \\ Alexey B. Mazrukho, Svetlana V. Titova, \\ Victor V. Maleev, German A. Shipulin
}

Author affiliations: Federal Budget Institute of Science Central Research Institute for Epidemiology, Moscow, Russia (K.V. Kuleshov, V.G. Dedkov, A.A. Deviatkin, V.V. Maleev, G.A. Shipulin); Federal Government Health Institution Rostov-onDon Plague Control Research Institute, Rostov-on-Don, Russia (S.O. Vodop'ianov, V.D. Kruglikov, A.S. Vodop'ianov, R.V. Pisanov, A.B. Mazrukho, S.V. Titova); Research Institute of Occupational Health, Moscow (M.L. Markelov); Federal Budget Institute Chumakov Institute of Poliomyelitis and Viral Encephalitides, Moscow (A.A. Deviatkin)

DOI: http://dx.doi.org/10.3201/eid2211.151727

To the Editor: Cholera - a severe, waterborne, virulent enteric infection caused by toxigenic strains of Vibrio cholera-frequently causes epidemics in developing countries and sporadic cases or local outbreaks in developed countries. The geographic features of Russia and intensive globalization have established favorable conditions for travel-associated cholera from regions to which it is endemic. During 2005-2012, six such cases occurred in Russia; these cases were related to travel from India. Three of the cases were registered in 2010, three months before the cholera outbreak in Haiti, one of the most extensive outbreaks in recent history (1). We genetically analyzed 4 isolates collected in 2010 and 2012 using whole-genome sequencing (online Technical Appendix 1, http://wwwnc.cdc.gov/EID/article/22/11/15-1727Techapp1.pdf) and compared the results with a public data- 